\title{
Suppressor T Cell Clones from Patients with Acute Epstein-Barr Virus-induced Infectious Mononucleosis
}

\author{
Fred Wang," R. Michael Blaese," Kathryn C. Zoon, ${ }^{\star}$ and Giovanna Tosato" \\ ${ }^{*}$ Metabolism Branch, National Cancer Institute, Bethesda, Maryland 20892; and the Divisions of ${ }^{\ddagger}$ Virology and ${ }^{\S}$ Biochemistry and \\ Biophysics, Office of Biologics Research and Review, National Institutes of Health, Bethesda, Maryland 20892
}

\begin{abstract}
Suppression and/or cytotoxicity are believed to play an important role in the defense against Epstein-Barr virus (EBV) infection. To analyze the role of suppressor $T$ cells in relation to $E B V$, we sought to clone and study these $T$ cells. Analysis of $152 \mathrm{~T}$ cell clones derived from the peripheral blood of two patients with acute EBV-induced infectious mononucleosis (IM) yielded 11 highly suppressive clones that had no cytotoxic activity for the natural killer sensitive $\mathrm{K562}$ cell line, an autologous EBV-infected cell line, or an allogeneic EBV-infected B cell line. Four of six suppressor $\mathbf{T}$ cell clones also profoundly inhibited EBVinduced immunoglobulin production, and five of five clones delayed the outgrowth of immortalized cells. These results indicate that during acute IM, suppressor $T$ cells capable of inhibiting $B$ cell activation in the absence of cytotoxicity can be identified, and may play a key role in the control of EBV infection.
\end{abstract}

\section{Introduction}

Epstein-Barr virus (EBV) ${ }^{1}$ is an ubiquitous herpes virus that has a unique relationship with the immune system. In vitro EBV infects B cells in preference to all other blood cells (1), and as a consequence of infection these cells proliferate, differentiate into Ig-secreting cells, and eventually become immortalized (2-4). In vivo primary infection by EBV is the most common cause of infectious mononucleosis (IM) (5). Patients with IM have been shown to have a high number of EBV-infected B cells in their peripheral blood that are capable of continuous growth in vitro $(6,7)$. Yet patients with this illness very rarely develop monoclonal or polyclonal neoplasms composed of EBV-infected cells. This has been attributed to the vigorous host immune response, consisting of activated suppressor (8-11) and/or cytotoxic T cells (12-17), that develops during the course of the disease. Patients with a congenital disorder of this immune response, referred to as the $\mathrm{X}$-linked lymphoproliferative syndrome, experience fatal episodes of infectious mononucleosis $(18,19)$.

This work was presented in part in abstract form at a meeting of the American Society for Clinical Investigation in Washington, D.C., 1985.

Address reprint requests to Dr. Fred Wang, University of Chicago, Kovler Viral Oncology Laboratories, 910 East 58th Street, Chicago, IL 60637.

Received for publication 27 August 1985 and in revised form 2 September 1986

1. Abbreviations used in this paper: BSS, balanced salt solution; EBV, Epstein-Barr virus; IL-2, interleukin-2; IM, infectious mononucleosis; MDBK, Madin-Darby bovine kidney cell; MHC, major histocompatibility complex; PWM, pokeweed mitogen.

The Journal of Clinical Investigation, Inc.

Volume 79, January 1987, 7-14
After primary infection with EBV, normal individuals have a small but detectable number of circulating $B$ cells latently infected with EBV that are capable of immortal growth when cultured in vitro $(6,7,20)$. Control of these latently infected $B$ cells is also attributed to cytotoxic and/or suppressor $T$ cells that have been described in normal EBV-seropositive individuals (21-24). The importance of these immune $T$ cells is demonstrated by the appearance of EBV-induced B cell neoplasms in patients with acquired immunodeficiency syndrome (25) and in those treated with immunosuppressive drugs, such as cyclosporin A (26), or with an anti-T cell monoclonal antibody (27).

Much information has been accumulated to demonstrate a role for regulatory $\mathrm{T}$ cells in the defense against $\mathrm{EBV}$ infection $(28,29)$. However, unlike $T$ cell responses to a variety of antigens that have been analyzed in great detail and are relatively well understood (30), very little is known at present about $T$ cell recognition and regulation of EBV-infected B cells. A preliminary question to be addressed is the relationship among the $T$ cell regulatory mechanisms reported to contribute to the control of EBV-infected B cells, including suppression and specific and nonspecific killing. In this study we have asked whether suppression is an independent mechanism of immune defense to EBV, or whether the apparent suppression is really due to cytotoxic cells killing the B cells and thus preventing Ig production. To address this question, we attempted to isolate and expand suppressor $\mathrm{T}$ cell clones from individuals with EBV infection. Although we could not obtain suppressor $T$ cell clones from normal EBV-seropositive individuals, we readily obtained suppressor $\mathrm{T}$ cell clones from patients with acute EBV-induced infectious mononucleosis. These results demonstrate that suppression is a distinct defense mechanism against EBV-infected B cells.

\section{Methods}

Patients. Patients with EBV-induced IM fulfilling the diagnostic criteria previously reported (9) were referred to the National Institutes of Health from Georgetown University Health Center. Blood was obtained in preservative-free heparin from these IM patients and from normal EBVseropositive donors. Antibody titers to EBV-related antigens were determined by Dr. W. Henle, as previously described (31). Separation of mononuclear cells and enrichment of $T$ and $B$ cell subsets by rosetting with 2-aminoethylisothiouronium bromide-treated sheep red blood cells were performed as previously described (9). The nonrosetting populations containing $<2 \%$ sheep erythrocyte rosette-forming cells are referred to as "B cells." The rosetting population containing $<1 \%$ non-sheep erythrocyte rosette-forming cells are referred to as "T cells."

$T$ cell cloning. Fresh $T$ cells from normals and IM patients were cultured in 96-well roundbottom microtiter plates (Costar, Cambridge, MA) at serial twofold reductions in cell densities (400/well, 200/well, etc.) with a feeder layer of 20,000 normal autologous or allogeneic irradiated $(4,000 \mathrm{rad})$ mononuclear cells. The culture medium, referred to as 20\% Interleukin-2 (IL-2)-conditioned medium, consisted of RPMI 1640 medium (Gibco Laboratories, Grand Island, NY) supplemented with $2 \mathrm{mM}$ glutamine (Gibco Laboratories), $5 \mu \mathrm{g} / \mathrm{ml}$ gentamycin (Sigma 
Chemical Co., St. Louis, MO), 10\% heat-inactivated fetal calf serum (Gibco Laboratories), and 20\% delectinated human IL-2 (Cellular Products, Inc., Buffalo, NY). Positive wells were scored for the presence of large clumps of growing cells at $28 \mathrm{~d}$ by visual examination with phasecontrast microscopy. The precursor frequency of $T$ cells capable of longterm growth was calculated by Poisson statistics using the minimum chi square analysis method previously described by Taswell in a program written for a Wang computer by Robert Yarchoan (32). Positive wells, established at a calculated precursor frequency of $<0.7$ precursors/well, were expanded in Linbro flat-bottom 24-well plates (surface area per well, $2.0 \mathrm{~cm}^{2}$ ) (Flow Laboratories, Inc., McLean, VA) with 20\% IL-2conditioned medium. Subsequently, the clones were maintained in culture by feeding with IL-2-conditioned medium and expanded when necessary. Initial functional testing was performed as soon as sufficient numbers of cells were available for each clone, 4-6 wk after the limiting dilution cloning was set up. The selected clones were retested repetitively thereafter for 12-16 wk, when most clones died. No feeder cells or other stimulants were added after the initial seeding.

Establishment of B cell lines. EBV-infected B cell lines were established from patients and normals by incubating $B$ cells at a concentration of $500,000 \mathrm{cells} / \mathrm{ml}$ in 10-ml RPMI 1640 medium supplemented with 2 $\mathrm{mM}$ glutamine, $5 \mu \mathrm{g} / \mathrm{ml}$ gentamycin, and $10 \%$ heat-inactivated fetal calf serum (FCS) with $10 \%$ vol/vol EBV (filtered supernatant of the B95-8 line with at least $10^{6}$ transforming $\mathrm{U} / \mathrm{ml}$ ) in $25-\mathrm{cm}^{2}$ flasks (Corning Glass Works, Corning, NY).

Lymphocyte cultures and assay for suppression of Ig production. T cell suppression of pokeweed mitogen (PWM)-induced Ig production was determined by comparing the number of Ig-secreting cells produced by PWM-activated mononuclear cells cultured either alone or mixed in coculture with allogeneic $\mathrm{T}$ cells. Normal indicator mononuclear cells were cultured for 5-7 d in 96-well roundbottom microtiter plates (Costar) at the cell density of $100-125 \times 10^{3}$ cells/well without or with PWM (Gibco Laboratories) at the final dilution of 1:80. The indicator cells were either cultured alone or mixed in coculture with cloned $T$ cells at the indicated cell densities. These $T$ cells were extensively washed with Hank's balanced salt solution (HBSS) (Scott Laboratories, Fiskeville, RI) before coculture experiments to remove exogenous IL-2.

$T$ cell suppression of EBV-induced Ig production was evaluated by comparing the number of Ig-secreting cells produced by EBV-infected $B$ cells either cultured alone or mixed in coculture with autologous $T$ cells. B cells were cultured for 8-14 d in the presence of EBV (B95-8 strain) at the cell density of 50,000 B cells/well in 96-well roundbottom plates as the indicator response. Effector $T$ cells were added in coculture as above.

At the end of culture the number of Ig-secreting cells was assayed with a modified reverse-hemolytic plaque assay, as described (33). Plaques were read using a semiautomated plaque counter (Optomax, Inc., Hollis, $\mathrm{NH}$ ). Results are expressed as total number of plaque-forming cells (PFC) per culture. All assays were done at least in triplicate. The percent suppression was calculated as:

$\%$ suppression $=$

$$
100 \times\left(1-\frac{\text { PFC/culture of indicator cells }+ \text { effector T cells }}{\text { PFC/culture of indicator cells alone. }}\right) .
$$

Cytotoxicity assay. Cytotoxicity was measured using a 4.5-h chromium release assay. Target cells for cytotoxicity included EBV-infected B cell lines and the natural killer-sensitive K562 cell line obtained from the American Type Culture Collection, Rockville, MD. These targets were split $2 \mathrm{~d}$ before the cytotoxicity assay. On the day of the assay, 2 $\times 10^{6}$ targets resuspended in $100 \mu \mathrm{l}$ of balanced salt solution (BSS) supplemented with $10 \% \mathrm{FCS}$ were incubated at $37^{\circ} \mathrm{C}$ with $500 \mu \mathrm{Ci}$ of sodium chromate (ICN Pharmaceuticals, Inc., Irvine, CA) for $45 \mathrm{~min}$. Target cells were then washed five times in BSS and resuspended at a cell density of $5 \times 10^{4}$ cells $/ \mathrm{ml}$ in $10 \%$ FCS medium. Effector T cells from the T cell lines and clones were washed three times in HBSS and resuspended in $10 \%$ FCS medium. Cytotoxicity assays were performed in 96-well roundbottom microtiter plates and consisted of triplicate cultures con- taining $100 \mu \mathrm{l}$ of control or effector T cells and $100 \mu \mathrm{l}$ of labeled target cells. These cultures were incubated at $37^{\circ} \mathrm{C}$ for $4.5 \mathrm{~h}$, centrifuged at $550 \mathrm{~g}$ for $5 \mathrm{~min}$, and the supernatants were harvested with SCS harvesting frames and transfer tubes (Skatron, Inc., Sterling, VA) and counted. Each assay contained targets incubated with medium alone in the absence of effectors (spontaneous release), and targets incubated in 10\% Triton $\mathrm{X}-100$ (maximum release). Percent target lysis was calculated as:

$\%$ target lysis $=100 \times \frac{\text { experimental release }- \text { spontaneous release }}{\text { maximum release }- \text { spontaneous release }}$.

Experimental release equals the counts per minute in the supernatant of effectors and targets. In all the experiments the spontaneous release was $<30 \%$ of the maximum release.

Assay for outgrowth of EBV-infected B cells. Purified B cells $(5,000 /$ well) were cultured with EBV ( $50 \mu l$ of the filtered supernatant of the B95-8 cell line) in 96-well roundbottom microtiter plates with or without the addition of autologous $\mathrm{T}$ cells $\left(1 \times 10^{5}\right.$ cells/well $)$ in $10 \% \mathrm{FCS}$ medium. These included $T$ cells from $T$ cell clones established at the time of the acute disease, as well as fresh $T$ cells obtained after recovery. Control cultures included wells with infected $B$ cells alone and wells with $T$ cells alone. Plates were visually examined weekly with phase-contrast microscopy for evidence of outgrowth, and each well was scored at 3 and 4 wk of culture. Wells were considered positive for B cell outgrowth if clumps of large progressively growing cells were recognized, as described (34).

Assay for interferon. Interferon activity was quantified by a cytopathic effect inhibition assay, as previously described (35). Briefly, serial dilutions of test culture supernatants along with the National Institutes of Health standard gamma-interferon preparation $(\mathrm{Gg} 23-901-530)$ were added to flatbottom microtiter plates (Costar) containing confluent monolayers of Madin-Darby bovine kidney cells (MDBK) and the epithelial human amnion cell line (WISH, ATTC CCL25). After $18 \mathrm{~h}$ incubation and culture washing, vesicular stomatitis virus was added at a concentration of 0.5 plaque-forming units/well. After reincubation for $18 \mathrm{~h}$ plates were read for cytopathic effect. $1 \mathrm{U}$ of interferon is defined as the reciprocal of the dilution that inhibits viral replication by $50 \%$.

Cell surface phenotyping. Cell surface phenotyping was determined by fluorescence-activated cell sorter using OKT3, OKT4, OKT8, and OKT11 monoclonal antibodies (Ortho Diagnostics Systems, Inc., Raritan, $\mathrm{NJ}$ ) and a fluoresceinated goat anti-mouse antibody (Becton-Dickinson and Co., Mountain View, CA).

\section{Results}

Three normal EBV-seropositive individuals were selected for this study because their peripheral blood $\mathrm{T}$ cells consistently demonstrated high levels of characteristic "late acting" suppressor activity for autologous EBV-infected B cells in vitro (24). $\mathrm{T}$ cell cloning of peripheral blood $\mathrm{T}$ cells from these individuals was performed in IL-2-containing medium by limiting dilution techniques with a feeder layer of 20,000 irradiated $(4,000 \mathrm{rad})$ autologous or allogeneic mononuclear cells. In these three normals, the frequency of $\mathrm{T}$ cell precursors capable of long-term growth in IL-2-containing medium ranged between 1:9 (Fig. 1) and 1:60. Expansion of positive wells seeded with a calculated number of $\mathrm{T}$ cell precursors lower than 0.5 precursors/well yielded 167 cell clones. Each of these 167 clones, 47 clones from normal 1, 84 clones from normal 2, and 36 clones from normal 3 , was tested in parallel in vitro assays for both suppression of Ig production and cytotoxic activity. Suppression of Ig production was evaluated both in cultures of PWM-activated normal allogeneic mononuclear cells and cultures of EBV-infected autologous B cells. Cytotoxic activity was tested using three distinct cell targets, the autologous EBV-infected cell line, an allogeneic EBV-infected B cell line, and the natural killer sensitive K562 


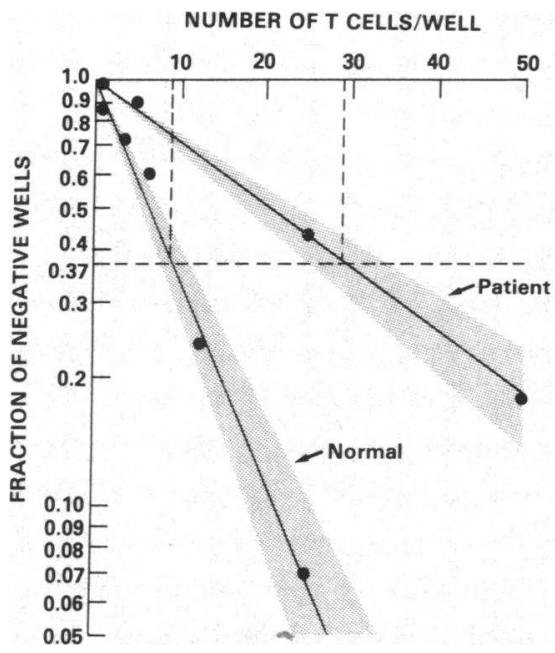

Figure 1. Precursor frequency analysis of peripheral blood T cells capable of longterm growth. The precursor frequency for normal $\mathrm{T}$ cells is 1 in 9, with 95\% confidence limits shown in shaded area. Precursor frequency for IM patient C.S. is 1 in 29.

cell line. Of these 167 clones, 156 suppressed by $<30 \%$ Ig production by allogeneic PWM-activated mononuclear cells (ratio, 1:1) or by autologous EBV-activated B cells (ratio, 2:1). In addition, each of these 156 clones had no significant cytotoxic activity ( $<20 \%$ at $80: 1$ effector-target ratio) when assayed on the autologous and an allogeneic EBV-infected B cell line. This failure to observe cytotoxic activity was not due to the target B cell line's inability to be lysed, because in each experiment it could be lysed by an alloreactive $T$ cell line. 11 of the 167 clones did manifest some inhibitory activity of B cell function (Table I). As can be seen, each of these 11 clones suppressed normal PWM-induced Ig production and killed the K562 cell line by $>30 \%$. Thus, $\mathrm{T}$ cell suppression of Ig production was in each case associated with "natural killer" activity. Only 1 of the 11 clones suppressed EBV-induced Ig production by autologous B cells by $>30 \%$, and this inhibitory activity was associated with $>30 \%$ cytotoxic activity for the autologous and an allogeneic EBV-induced B cell line. Thus, by this technique we were unable to isolate $T$ cell clones from normal peripheral blood that would suppress EBV-induced Ig production in the absence of cytotoxic function.

In contrast to EBV-seropositive normals, patients with acute EBV-induced IM have high levels of functionally activated suppressor $\mathrm{T}$ cells circulating in their peripheral blood that are capable of profoundly suppressing both PWM and EBV-activated cultures in vitro (8-11). We therefore turned to these patients in an attempt to obtain suppressor $T$ cell clones.

Peripheral blood $\mathrm{T}$ cells were purified from two patients with serologically confirmed EBV-induced acute IM. Cloning was performed in limiting dilution cultures of purified peripheral blood $\mathrm{T}$ cells in $20 \%$ IL-2-conditioned medium with a feeder layer of irradiated allogeneic mononuclear cells $(20,000 /$ well $)$, the identical technique illustrated above with two of the normal individuals. The precursor frequency of $T$ cells capable of longterm growth from these IM patients was found to be 1 in 29 for patient C.S. (Fig. 1) and 1 in 30 for patient H.C. (data not shown). Thus, similar to normal individuals, a high proportion of the peripheral blood T cells from patients with acute IM are capable of clonal expansion in vitro in the presence of IL-2.

$72 \mathrm{~T}$ cell clones were obtained from patient C.S. and 80 from patient H.C. by expansion of the positive wells that had been seeded with a calculated number of $T$ cells corresponding to $<0.7$ precursors/well. All of these $152 \mathrm{~T}$ cell clones were tested for their ability to suppress PWM-induced Ig production by cocultured normal allogeneic mononuclear cells 4-6 wk after cell cloning, as soon as sufficient numbers of cells were available. Five clones from patient C.S. and six clones from patient H.C. suppressed PWM-induced Ig production by $\geq 70 \%$ (Table II) on three separate testings during a 2-wk period, and were selected for further investigation. A dose response analysis of the activity

Table I. Assays of Suppressor and Cytotoxic Activity of Selected T Cell Clones from Three Normal Individuals

\begin{tabular}{|c|c|c|c|c|c|c|}
\hline \multirow[b]{2}{*}{ Normal" } & \multirow[b]{2}{*}{$\mathrm{T}$ cell clone } & \multicolumn{2}{|c|}{$\begin{array}{l}\text { Percent suppression of normal } \\
\text { immunoglobulin production* }\end{array}$} & \multicolumn{3}{|l|}{$\begin{array}{l}\text { Cytotoxicity: percent lysis } \\
\text { Targets }\end{array}$} \\
\hline & & PWM-induced & EBV-induced & Autologous EBV B line & Allogeneic EBV B line & K562 \\
\hline \multirow[t]{6}{*}{1} & 4B26-6 & $68.4(1.4)$ & $-6.2(0.4)$ & $0.6(2.8)$ & $32.1(3.3)$ & $42.1(0.6)$ \\
\hline & $4 B 26-10$ & $49.2(2.8)$ & $-2.8(0.5)$ & $3.4(1.9)$ & $0.4(0.6)$ & $38.5(0.9)$ \\
\hline & 4B26-11 & $71.4(0.8)$ & $2.4(2.1)$ & $-1.8(0.3)$ & $51.3(0.9)$ & $61.6(2.2)$ \\
\hline & $4 B 26-32$ & $54.3(2.1)$ & $4.6(0.9)$ & $-1.6(0.8)$ & $-1.8(3.1)$ & $48.3(1.6)$ \\
\hline & $4 B 26-35$ & $38.6(0.7)$ & $8.2(1.3)$ & $-5.6(1.2)$ & $3.6(2.8)$ & $49.6(2.4)$ \\
\hline & 4B26-61 & $62.4(1.2)$ & $-1.6(0.7)$ & $8.4(2.1)$ & $-2.4(2.1)$ & $36.8(2.9)$ \\
\hline \multirow[t]{3}{*}{2} & $39 B 27-26$ & $76.4(1.7)$ & $-6.4(2.2)$ & $12.6(1.6)$ & $20.1(1.8)$ & $62.1(0.9)$ \\
\hline & 39B27-32 & $34.6(1.8)$ & $8.3(3.3)$ & $23.1(1.6)$ & $27.6(2.1)$ & $30.0(2.3)$ \\
\hline & 39B27-36 & $88.7(2.4)$ & $-8.2(2.1)$ & $27.3(1.1)$ & $22.1(2.3)$ & $57.4(1.6)$ \\
\hline \multirow[t]{2}{*}{3} & 72B27-84 & $42.9(1.9)$ & $36.8(1.6)$ & $42.1(2.3)$ & $38.6(1.2)$ & $52.1(1.6)$ \\
\hline & $72 B 27-91$ & $61.7(1.3)$ & $12.6(1.8)$ & $18.7(1.9)$ & $12.7(1.6)$ & $41.2(2.1)$ \\
\hline
\end{tabular}

* Values are the arithmetic mean \pm SEM of percent suppression. PWM-induced cultures consisted of 100,000 T cells from the indicated clones and 100,000 normal mononuclear cells. Testing was performed on the 6th d of culture. EBV-induced cultures contained 50,000 B cells and 100,000 cloned autologous $\mathrm{T}$ cells, and were tested on the 14 th $\mathrm{d}$ of culture. ${ }^{\ddagger}$ Arithmetic mean \pm SEM of triplicate determinations performed at an effector-target ratio of 80:1. $\mathrm{T}$ cell cloning for normals 1 and 2 was performed using allogeneic irradiated mononuclear cells as feeder cells. Autologous irradiated mononuclear cells were used as feeder cells for normal 3. 
Table II. Phenotype and Assays of Suppressor and Cytotoxic Activity of Selected T Cell Clones from Patients with Acute IM

\begin{tabular}{|c|c|c|c|c|c|c|c|}
\hline \multirow[b]{2}{*}{ Patient } & \multirow[b]{2}{*}{ T cell clone } & \multirow[b]{2}{*}{ Phenotype } & \multicolumn{2}{|c|}{$\begin{array}{l}\text { Percent suppression of normal } \\
\text { immunoglobulin production* }\end{array}$} & \multicolumn{3}{|c|}{$\begin{array}{l}\text { Cytotoxicity: percent lysis } \\
\text { Targets }\end{array}$} \\
\hline & & & PWM-induced & EBV-induced & $\begin{array}{l}\text { Autologous } \\
\text { EBV B line }\end{array}$ & $\begin{array}{l}\text { Allogeneic } \\
\text { EBV B line }\end{array}$ & K562 \\
\hline \multirow[t]{5}{*}{1 (C.S.) } & 65.05 & $\mathrm{~T} 3+, \mathrm{T} 11+, \mathrm{T} 8-, \mathrm{T} 4+$ & $74.3(1.2)$ & ND & $6.7(0.7)$ & $-1.3(0.9)$ & $3.0(0.9)$ \\
\hline & 65.11 & $\mathrm{~T} 3+, \mathrm{T} 11+, \mathrm{T} 8-, T 4+$ & $98.0(0.6)$ & ND & $1.4(1.9)^{8}$ & $4.1(3.6)$ & $6.8(2.8)$ \\
\hline & 65.55 & $\mathrm{~T} 3+, \mathrm{T} 11+, \mathrm{T} 8+, \mathrm{T} 4-$ & $78.0(3.2)$ & ND & $0.0(1.1)^{8}$ & $-2.5(1.0)$ & $-0.5(0.8)$ \\
\hline & 65.58 & $\mathrm{~T} 3+, \mathrm{T} 11+, \mathrm{T} 8+, \mathrm{T} 4-$ & $92.7(0.3)$ & ND & $6.8(2.3)$ & $-2.4(0.6)$ & $1.8(1.6)$ \\
\hline & 65.66 & $\mathrm{~T} 3+, \mathrm{T} 11+, \mathrm{T} 8+, \mathrm{T} 4-$ & $89.3(2.7)$ & ND & $0.3(0.7)^{8}$ & $0.3(0.9)$ & $0.2(1.2)$ \\
\hline \multirow[t]{6}{*}{2 (H.C.) } & 92.06 & $\mathrm{~T} 3+, \mathrm{T} 11+, \mathrm{T} 8-, \mathrm{T} 4+$ & $76.7(3.5)$ & $65.3(4.1)$ & $0.2(0.8)$ & $4.4(2.8)$ & $1.0(1.6)$ \\
\hline & 92.18 & $\mathrm{~T} 3+, \mathrm{T} 11+, \mathrm{T} 8-, \mathrm{T} 4+$ & $85.7(0.7)$ & $9.0(28.2)$ & $1.2(3.4)$ & $-2.3(1.8)$ & $2.7(1.9)$ \\
\hline & 92.24 & $\mathrm{~T} 3+, \mathrm{T} 11+, \mathrm{T} 8-, \mathrm{T} 4+$ & $94.7(0.3)$ & $-11.3(14.8)$ & $-1.3(2.3)^{8}$ & $-7.0(2.8)$ & $-0.5(2.6)$ \\
\hline & 92.50 & $\mathrm{~T} 3+, \mathrm{T} 11+, \mathrm{T} 8-, \mathrm{T} 4+$ & $68.7(3.2)$ & $63.7(5.5)$ & $-1.6(0.4)$ & $2.3(2.3)$ & $-1.0(1.9)$ \\
\hline & 92.56 & $\mathrm{~T} 3+, \mathrm{T} 11+, T 8+, \mathrm{T} 4-$ & $79.0(2.0)$ & $90.3(1.8)$ & $-0.8(1.9)^{8}$ & $-9.3(1.9)$ & $-3.2(1.0)$ \\
\hline & 92.68 & $\mathrm{~T} 3+, \mathrm{T} 11+, \mathrm{T} 8-, T 4+$ & $74.7(1.2)$ & $72.3(12.2)$ & $0.0(1.6)$ & $-6.6(1.7)$ & $-1.2(1.6)$ \\
\hline
\end{tabular}

* Values are the arithmetic mean \pm SEM of percent suppression as described in Methods. PWM-induced cultures were set up with 100,000 cloned $T$ cells and 125,000 normal mononuclear cells. They were tested on days 5-7 of culture. EBV-induced cultures were performed with 25,000 cloned T cells and 50,000 autologous B cells and were tested on day 8 of culture. ${ }^{\ddagger}$ Arithmetic mean \pm SEM of triplicate values at an effectortarget ratio of 50:1. Experiments for these clones were done at an effector-target ratio of 40:1.

of one of these suppressor clones is shown in Table III. As few as $12,500 \mathrm{~T}$ cells of this clone suppressed the plaque-forming response of 125,000 normal mononuclear cells to PWM by $>70 \%$. The coculture of a control $\mathrm{T}$ cell clone with no apparent function yields no suppression, showing that suppression in these assays is not due to a nonspecific effect.

After establishing the suppressor nature of these 11 clones, we examined each for its ability to kill the K562 cell line, an autologous EBV-infected B cell line, and an allogeneic EBVinfected B cell line (Table II). Testing for cytotoxicity was initially performed 7-9 wk after cloning. In sharp contrast to the clones from normal EBV-immune individuals, none of these 11 suppressor $\mathrm{T}$ cell clones from the IM patients was capable of killing any of the targets tested. This lack of cytotoxicity was a consistent

Table III. Suppression of Normal PWM-induced Ig Production by Clone 92.24*

\begin{tabular}{llll}
\hline Type of added T cells & $\begin{array}{l}\text { Number } \\
\text { of added } \\
\text { T cells }\end{array}$ & $\begin{array}{l}\text { Mean } \\
\text { PFC/culture }\end{array}$ & $\begin{array}{l}\text { Percent } \\
\text { suppression }\end{array}$ \\
\hline None & None & 1,338 & - \\
Control T cell clone & 100,000 & 1,681 & $-17 \%(2.31)$ \\
Clone 92.24 & 100,000 & $<1$ & $100 \%$ \\
& 50,000 & 3 & $100 \%(0.33)$ \\
& 25,000 & 21 & $98 \%(0.67)$ \\
12,500 & 379 & $74 \%(1.76)$ \\
& 6,250 & 712 & $50 \%(1.76)$ \\
& 3,125 & 623 & $68 \%(10.33)$ \\
& 1,063 & 1,302 & $6 \%(18.41)$ \\
532 & 1,375 & $4 \%(8.42)$
\end{tabular}

* Indicator cultures consisted of 125,000 normal mononuclear cells stimulated with PWM on day 0 . These normal cells were cultured alone or in coculture with various numbers of the suppressor $\mathrm{T}$ cell clone 92.24 or a nonfunctional $\mathrm{T}$ cell clone. finding in repeated testing over an 8-wk period. It should be noted that each clone demonstrated persistent suppressor activity in suppressor assays done either simultaneously or after the cytotoxicity assays. A representative experiment illustrating these cytotoxic studies is shown in Fig. 2. Normal mononuclear cells used as the positive control demonstrated good killing of the K562 targets, whereas the three suppressor clones examined in this experiment had no cytotoxic activity at effector-target ratios up to $80: 1$ or 100:1 (Fig. $2 A$ ). Similarly, the three clones shown did not kill the autologous EBV-infected targets, while the positive control alloreactive cytotoxic $\mathrm{T}$ cell line killed the EBVinfected targets well (Fig. $2 B$ ). This failure to kill could reflect the absence of specific antigenic stimulation during a prolonged (7-9 wk) culture period. Since it is believed that the cytotoxic $\mathrm{T}$ cell response during acute IM is induced by EBV-infected B cells (36), we have exposed four suppressor T cell clones (92.06, 92.18, 92.24, and 92.50) to the autologous EBV-infected and irradiated $(10,000 \mathrm{rad}) \mathrm{B}$ cells ( $\mathrm{T}$ cell-B cell ratios, 1:1 and 1:0.1) in the presence or absence of IL-2. At the end of a 5-d culture period none of the clones had acquired an ability to kill K562 and/or autologous EBV-infected B cell targets at an effector-target ratio of 50:1; maximum killing was $6 \%$. In parallel testing each clone suppressed Ig production by normal PWMactivated mononuclear cells by $>80 \%$ (data not shown). These findings demonstrate that $T$ cell clones derived from IM patients can suppress Ig production in vitro in the absence of detectable cytotoxic activity.

EBV-induced Ig production cannot be reliably investigated in allogeneic coculture due to major histocompatibility complex (MHC) restrictions in this system (37). We therefore obtained blood from one of the IM patients (H.C.) after recovery, $\sim 15$ wk after the initial bleed, allowing us to examine whether the autologous $T$ cell clones could regulate the activation of $B$ cells by EBV. In these experiments 50,000 EBV-infected B cells from patient H.C. were cultured either alone or mixed with 25,000 $\mathrm{T}$ cells from each of the six autologous $\mathrm{T}$ cell clones that had $>70 \%$ suppressor activity for normal PWM-induced Ig produc- 

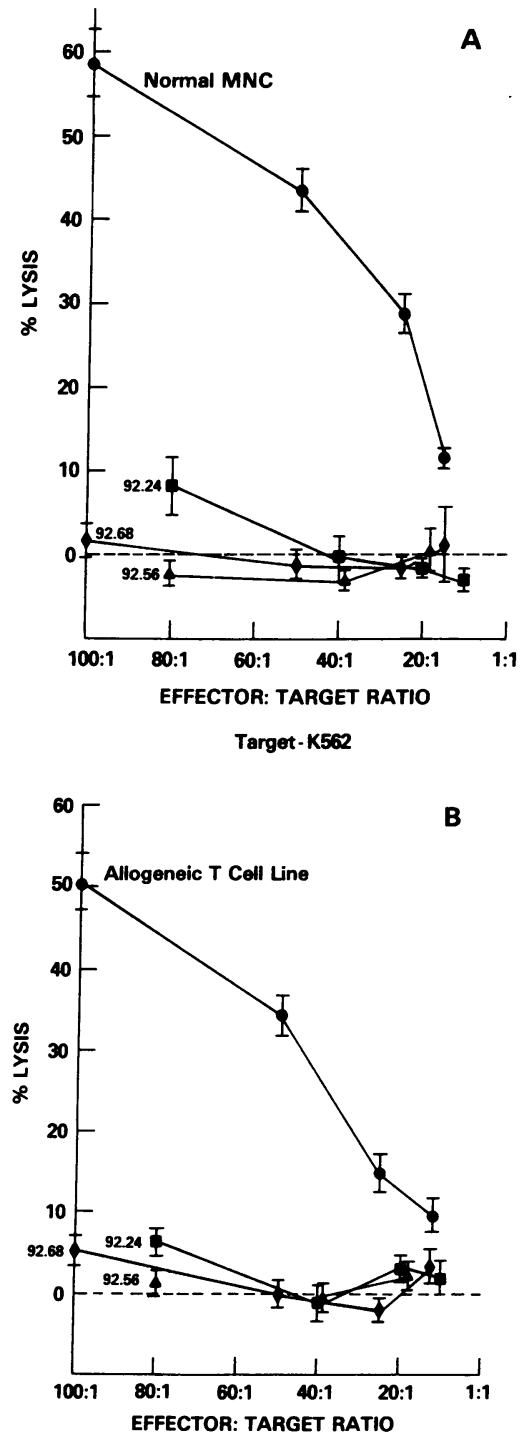

Target-Autologous EBV B cell Line
Table IV. Effect of Suppressor T Cells on EBV-induced B Cell Outgrowth*

\begin{tabular}{lccc}
\hline Type of added T cells & $\begin{array}{l}\text { Number } \\
\text { of added } \\
\text { T cells }\end{array}$ & $\begin{array}{l}\text { Positive } \\
\text { wells at } \\
3 \mathbf{w k}^{\ddagger}\end{array}$ & $\begin{array}{c}\text { Positive } \\
\text { wells at } \\
\mathbf{w k}\end{array}$ \\
\hline $\begin{array}{l}\text { None } \\
\text { Autologous }\end{array}$ & None & $10 / 10$ & $10 / 10$ \\
$\quad$ convalescent T cells & 100,000 & $0 / 10$ & $0 / 10$ \\
& 50,000 & $5 / 10$ & $5 / 10$ \\
& 25,000 & $6 / 10$ & $7 / 10$ \\
Clone 92.06 & 100,000 & $3 / 10$ & $10 / 10$ \\
Clone 92.18 & 100,000 & $0 / 5$ & $5 / 5$ \\
Clone 92.24 & 100,000 & $3 / 10$ & $10 / 10$ \\
Clone 92.50 & 100,000 & $0 / 10$ & $5 / 10$ \\
Clone 92.68 & 100,000 & $4 / 10$ & $10 / 10$ \\
Control clone 92.75 & 100,000 & $10 / 10$ & $10 / 10$ \\
\hline
\end{tabular}

* 5,000 B cells plus EBV were cultured alone or with the autologous T cells from peripheral blood or clones and were evaluated for outgrowth weekly for 4 wk.

${ }^{\ddagger}$ Wells were visually scored for growth as described in Methods. Results are expressed as positive wells per number of wells cultured.
Figure 2. Representative experiments testing selected $\mathrm{HC}$ suppressor $\mathrm{T}$ 92.56) for cytotoxicity against the $(A)$ NK target $\mathrm{K} 562$ and $(B)$ the autologous EBV-induced $\mathrm{B}$ cell target. $(A)$ Normal mononuclear cells represent the positive control for cytolytic activity against $\mathrm{K} 562$. (B) An alloreactive T cell line with cytolytic activity is included as a positive control. cell clones $(92.24,92.68$,

tion. At the time of this testing the $T$ cell clones had been in culture for $\sim 15 \mathrm{wk}$. Four of these six $\mathrm{T}$ cell clones suppressed the plaque-forming cell response of autologous EBV-activated B cells by $>60 \%$ (Table II). The other two clones that also markedly suppressed PWM-induced Ig failed to suppress EBV-induced Ig production at this cell ratio.

We next asked if these $T$ cell clones from patient H.C. that were capable of suppressing without killing could regulate another assay of EBV activation, immortalization or outgrowth of autologous B cells freshly infected with EBV. In these experiments, 5,000 H.C. B cells were infected with EBV and cultured alone or with 100,000 H.C. T cells, whose activity was to be tested. The $\mathrm{T}$ cells used included H.C. $\mathrm{T}$ cells obtained after recovery from IM, one H.C. T cell clone that had no apparent function, and five of the H.C. T cell clones demonstrating $>70 \%$ suppressor activity. One of these clones (92.56) stopped growing after 16 wk and could not be tested; the remaining clones were tested 17 wk after cloning. By 3 wk after initiation of culture, all wells containing EBV-infected $B$ cells alone showed evidence of outgrowth (Table IV). Outgrowth from wells containing EBV- activated B cells and 100,000 T cells from each of the five suppressor clones was clearly inhibited at $3 \mathrm{wk}$. This outgrowth inhibition was not due to nonspecific cell crowding effects since no inhibition of $B$ cell outgrowth was seen in the presence of the nonfunctional H.C. clone 92.75. After 4 wk in culture, however, most wells containing the suppressor clones did show evidence of outgrowth. Thus, the suppressor clones significantly delayed, but did not prevent, the outgrowth of freshly EBVinfected B cells. As expected, the control wells containing $T$ cells from the patient during convalescence completely inhibited the outgrowth of autologous EBV-infected B cells (38).

To explore the mechanism of suppression by IM T cell clones, we tested cell-free supernatants for their ability to inhibit Ig production. Five suppressor $\mathrm{T}$ cell clones and a control nonsuppressor $\mathrm{T}$ cell clone that had been in continuous culture for 812 wk were incubated in $10 \%$ FCS medium at a cell density of $1 \times 10^{6} \mathrm{cells} / \mathrm{ml}$ for 1,3 , and $5 \mathrm{~d}$, when supernatants were removed for testing. Unlike the $\mathrm{T}$ cells from the inhibitory clones, mononuclear cells, their supernatants had little or no suppressive effect (Table V). When tested for the presence of interferon activity on WISH cells, each of the 5-d culture supernatants of the suppressor $\mathrm{T}$ cell clones contained small amounts of interferon (16-40 U/ml). This was identified as gamma interferon, since these supernatants had no protective effect $(<5 \mathrm{U} / \mathrm{ml})$ when tested on MDBK cells. In contrast, the supernatant of a control nonsuppressor clone was negative for interferon. In further analysis of the mechanism for $T$ cell suppression, we tested for the possibility that a relative deficiency of IL-2, removed by the IL-2-dependent suppressor $T$ cell clones, could account for inhibition of Ig production by normal cocultured cells. To this end, recombinant human IL-2 (gift of Cetus Corp., Berkeley, CA) was added to normal mononuclear cells cultured in the presence of PWM either alone or with T cells from two suppressor $T$ cell clones (92.06 and 92.50). In data not shown, recombinant IL-2 at final concentrations ranging between 10 and $1,000 \mathrm{U} / \mathrm{ml}$ failed to reverse inhibition by the suppressor clones. which markedly suppressed Ig production by normal cocultured 
Table V. Production of Interferon by Suppressor

$T$ Cell Clones from Patients with Acute IM

\begin{tabular}{llllll}
\hline & \multicolumn{3}{l}{ Percent suppression of normal Ig production by: } \\
\cline { 2 - 4 } & \multicolumn{3}{c}{ Supernatants* } & \\
\cline { 3 - 5 } Clone & Cells* & Day 1 & Day 3 & Day 5 & $\begin{array}{l}\text { Interferon } \\
\text { production }\end{array}$ \\
\hline & & & & & U/ml \\
65.05 & 81 & 16 & 9 & 8 & 40 \\
65.11 & 87 & 22 & 27 & 20 & 25 \\
92.06 & 89 & -15 & -8 & 5 & 25 \\
92.24 & 84 & -34 & 14 & 8 & 25 \\
92.50 & 94 & 28 & 1 & 7 & 16 \\
Control & 4 & 12 & 18 & -10 & 0 \\
\hline
\end{tabular}

* Values are the arithmetic mean of suppression in triplicate determinations. Normal mononuclear cells $(100,000)$ were cultured in the presence of PWM with T cells $(100,000)$ from the indicated clones or their cell-free supernatants at a final concentration of $50 \%$. These supernatants were obtained by incubating the indicated $\mathrm{T}$ cell clones at a cell density of $1 \times 10^{6} / \mathrm{ml}$ in $10 \%$ FCS medium for 1,3 , or $5 \mathrm{~d}$, and were stored at $-20^{\circ} \mathrm{C}$ before testing for suppression and interferon activity.

${ }^{\ddagger}$ Testing for interferon production was performed on the supernatants of $\mathrm{T}$ cell clones cultured for $5 \mathrm{~d}$ in 10\% FCS medium at a cell density of $1 \times 10^{6} / \mathrm{ml}$. The results shown derive from testing on WISH cells.

Separate testing showed that the recombinant IL-2 allowed maximal $\mathrm{T}$ cell proliferation at a final concentration of $50 \mathrm{U} / \mathrm{ml}$

Cell surface antigen phenotypes of the 11 suppressor $\mathrm{T}$ cell clones from IM patients are shown in Table II. All clones were T3 and T11 positive. Three T cell clones from patient C.S. were T8 positive, and two were T4 positive. Five of the T cell clones from patient H.C. were $\mathrm{T} 4$ positive, and one was $\mathrm{T} 8$ positive.

\section{Discussion}

One of the clearest examples of balance between the immune system and disease is represented by EBV infection. EBV is an ubiquitous virus that infects most of the world's adult population (39). Primary infection with this virus is either asymptomatic or results in the usually benign disease of acute infectious mononucleosis (5). Recovery is followed by a long-lasting and generally asymptomatic latent state of infection $(7,39,40)$. Suppression of the normal immune response by agents such as cyclosporin A (26) or an anti-T cell monoclonal antibody (27) and suppression in association with congenital or acquired immunodeficiencies $(18,19,25)$ have, however, resulted in the emergence of EBV-induced malignancies.

This balance between the immune response and EBV infection is closely paralleled by in vitro studies that offer a unique opportunity for investigation. In vitro studies have shown that EBV is capable of activating B cells to proliferate, differentiate into Ig-producing cells, and eventually transform into immortal B cell lines (2-4). EBV-related regulatory $T$ cells can prevent these effects of EBV activation in vitro $(26,27)$. T cell suppression and cytotoxicity have been identified as the mechanisms responsible for the regulation of EBV-infected B cells (8-17, 21-24). However, there has been controversy over whether these two functions are distinct, and over their relative contribution to the control of EBV infection. Previous studies describing these functions have used purified but polyclonal populations of peripheral blood $\mathrm{T}$ cells, so what was measured as suppression could have been merely the consequence of cytotoxic activity against the indicator cells in assays of suppression.

Our approach for studying the relationship between suppression and cytotoxicity in the immunoregulation of EBV infection was to clone and expand $T$ cells from the peripheral blood of either EBV-immune normals or patients with acute EBV-induced IM. Regulatory cells for EBV infection have been described, although with distinct characteristics, in each of these groups. T cells from EBV-seropositive individuals profoundly inhibit the proliferation, differentiation, and in vitro outgrowth of autologous EBV-infected B cells in coculture $(21,24,41)$. These regulatory cells appear to be specific since they have generally been identified only in EBV-immune individuals and appear to inhibit only EBV-activated autologous or MHC-compatible $B$ cells $(21,22,24,42)$. In contrast, $T$ cells obtained from the peripheral blood of patients with acute IM markedly inhibit the activation of autologous as well as allogeneic B and $T$ cells that have been activated by any of a variety of antigens or mitogens $(8-11,14-17)$. Thus, IM T cell inhibition appears to be unrestricted, EBV nonspecific, and without a preference for cell target.

We were successful in isolating clonal populations of $\mathrm{T}$ cells from the peripheral blood of a patient with acute IM that could markedly inhibit EBV-activated B cells but did not manifest detectable cytotoxic activity. Our approach involved cloning of the peripheral blood $\mathrm{T}$ cells and their subsequent expansion in the presence of IL-2. Selection was based exclusively on the ability of the T cell clones to markedly suppress PWM-induced Ig production by normal allogeneic mononuclear cells. On further testing none of these clones selected in this manner demonstrated significant cytotoxicity for three targets that included an autologous EBV-induced B cell line, an allogeneic EBV-induced B cell line, and the natural killer-sensitive K562 cell line. Suppression of EBV-induced Ig production was not used as an initial screening procedure because $\mathrm{MHC}$ restrictions prevent the study of EBV regulation in allogeneic cell combinations (37). It is therefore possible that inhibitory clones exist in the blood of patients with acute IM that regulate EBV-infected B cells, but not $B$ cells activated by other means. Since blood was available from one of the IM patients after recovery, we could study the effects of the previously selected $T$ cell clones from this patient on fresh autologous B cells stimulated with EBV. Four of the six $T$ cell clones that profoundly suppressed normal PWM-induced Ig production also markedly inhibited EBV-induced Ig production. Furthermore, five of five clones tested significantly delayed the outgrowth of EBV-transformed cells in vitro. It is unclear why two clones (92.18 and 92.24) failed to suppress EBV-induced Ig production and yet did delay the outgrowth of EBV-infected B cells. One possible explanation is that much higher T-to-B cell ratios were used in the outgrowth assays than in the assays for suppression, and this may have contributed to the difference in response.

To explore the mechanism of inhibition by IM suppressor and noncytotoxic $\mathrm{T}$ cell clones we examined the possibility that a relative deficiency of IL-2 removed by the IL-2-dependent $T$ cell clones could account for the suppression. In addition, we tested the supernatants of suppressor $T$ cell clones for the presence of inhibitory mediators. While the addition of IL-2 at high 
concentrations failed to reverse $T$ cell suppression, gamma interferon was present in the supernatants of all suppressor $\mathrm{T}$ cell clones examined, though at low levels ranging between 16 and $40 \mathrm{U} / \mathrm{ml}$. A control clone produced no interferon. It is possible that gamma interferon secretion is the mechanism of inhibition by IM suppressor $T$ cells, because recombinant gamma interferon at comparable concentrations $(10-50 \mathrm{U} / \mathrm{ml})$ has been shown to profoundly suppress EBV-induced Ig production (43). This possibility, however, needs further analysis, since cell-free supernatants of the suppressor $T$ cell clones containing the gamma interferon failed to show significant suppression.

The growth of functional suppressor $\mathrm{T}$ cell clones from IM patients is unlikely to result solely from allostimulation from the feeder cells used during the initial days of culture, because we were unable to obtain similar clones from normal individuals using identical methods. In addition, it is known that IM T cells respond poorly to allostimulation when compared with normal $T$ cells $(44,45)$, and that the frequency of alloreactive $T$ cell clones in normal individuals is only from 1:200 to 1:600 (46).

The cell surface phenotyping of these $T$ cell clones was also somewhat surprising. Acute IM is characterized by a T cell lymphocytosis, and a major component of this elevated lymphocyte number is composed of T cells bearing the T8 (suppressor/cytotoxic) surface antigen (47). It was therefore surprising that 7 of the $11 \mathrm{~T}$ cell clones from the IM patients were $\mathrm{T} 4$ positive/ T8 negative. Since these were T4-positive cells, we must consider whether they were inducers of suppression rather than suppressor-effector cells. These clones were, however, able to suppress EBV-induced Ig production by $T$ cell-depleted population of $B$ cells, strongly suggesting that the cells do indeed have suppressor effector activity.

Thus suppressor $\mathrm{T}$ cell clones that are capable of blocking both PWM- and EBV-induced Ig production as well as delaying the outgrowth of EBV-infected B cells without detectable cytotoxicity can be grown from the peripheral blood of IM patients. Using identical culture techniques, similar clones could not be identified in the blood of any three normal EBV-seropositive individuals. In these cases all the inhibitory $\mathrm{T}$ cell clones were nonspecifically cytotoxic for at least some of the target cell lines used, and may thus represent natural or lymphokine-activated killer cells (48). This failure is likely due to a relatively low frequency of EBV-related regulatory cells in normal EBV-immune blood, and it is possible that different approaches of isolating these cells will be successful.

These studies establish a distinction between suppression and cytotoxicity in $\mathrm{T}$ cells derived from patients with acute EBVinduced IM. These regulatory cells may play an important role in the control of primary EBV infection by inhibiting without killing EBV-infected B cells. Suppression, therefore, provides a distinct mechanism for the control of EBV infection.

\section{Acknowledgments}

We are grateful to Dr. Gerald Marti for his assistance with the cell sorter analyses, to Dr. Werner Henle for determining antibody titers to EBV in the study group, to the personnel of Georgetown University Student Health Center for referring the patients.

\section{References}

1. Jondal, M., and G. Klein. 1973. Surface markers on human B and T lymphocytes. II. Presence of Epstein-Barr virus receptors on B lymphocytes. J. Exp. Med. 138:1365-1378.
2. Gerber, P., and B. H. Hoyer. 1971. Induction of cellular DNA synthesis in human leukocytes by Epstein-Barr virus. Nature (Lond.). 231:46-47.

3. Rosen, A., P. Gergely, M. Jondal, G. Klein, and S. Britton. 1977. Polyclonal immunoglobulin production after Epstein-Barr virus infection of human lymphocytes in vitro. Nature (Lond.). 267:52-54.

4. Henle, W., V. Diehl, G. Kohn, H. zur Hausen, and G. Henle. 1967. Herpes type virus and chromosome marker in normal leukocytes after growth with irradiated Burkitt cells. Science (Wash. DC). 157:10641065.

5. Henle, G., W. Henle, and V. Diehl. 1968. Relation of Burkitt's tumor-associated herpes-type virus to infectious mononucleosis. Proc. Natl. Acad. Sci. USA. 59:94-101.

6. Rocchi, G. A., A. DeFelici, G. Ragona, and A. Heinz. 1977. Quantitative evaluation of Epstein-Barr virus-infected mononuclear peripheral blood leukocytes in infectious mononucleosis. N. Engl. J. Med. 296: 132-134.

7. Tosato, G., S. Straus, W. Henle, S. E. Pike, and R. M. Blaese. 1985. Characteristic $T$ cell dysfunction in patients with chronic active Epstein-Barr virus infection (chronic infectious mononucleosis). J. Immunol. 134:3082-3088.

8. Haynes, B. F., R. T. Schooley, C. R. Payling-Wright, J. E. Grouse, R. Dolin, and A. S. Fauci. 1979. Emergence of suppressor cells of immunoglobulin synthesis during acute Epstein-Barr vịus-induced infectious mononucleosis. J. Immunol. 123:2095-2101.

9. Tosato, G., I. Magrath, I. Koski, N. Dooley, and R. M. Blaese. 1979. Activation of suppressor T cells during Epstein-Barr virus-induced infectious mononucleosis. N. Engl. J. Med. 301:1133-1137.

10. Johnsen, H. E., M. Madsen, and T. Kristensen. 1979. Lymphocyte subpopulations in man: suppression of PWM-induced B-cell proliferation by infectious mononucleosis T cells. Scand. J. Immunol. 10:251-255.

11. Reinherz, E. L., C. O'Brien, P. Rosenthal, and S. F. Schlossman. 1980. The cellular basis for viral-induced immunodeficiency: analysis by monoclonal antibodies. J. Immunol. 125:1269-1274.

12. Svedmyr, E., and M. Jondal. 1975. Cytotoxic effector cells specific for $B$ cell lines transformed by Epstein-Barr virus are present in patients with infectious mononucleosis. Proc. Natl. Acad. Sci. USA. 72:16221626.

13. Tursz, T., W. H. Fridman, A. Senik, A. Tsapis, and M. Fellous. 1977. Human virus-infected target cells lacking HLA antigens resist specific T-lymphocyte cytolysis. Nature (Lond.). 269:806-808.

14. Lipinski, M., W. H. Fridman, T. Turz, C. Vincent, D. Pious, and $M$. Fellous. 1979. Absence of allogeneic restriction in human T-cellmediated cytotoxicity to Epstein-Barr virus-infected target cells. J. Exp. Med. 150:1310-1322.

15. Seeley, J., E. Svedmyr, O. Weiland, G. Klein, E. Moller, E. Ericksson, K. Andersson, and L. Van der Waal. 1981. Epstein-Barr virus selective $T$ cells in infectious mononucleosis are not restricted to HLAA and B antigens. J. Immunol. 127:293-300.

16. Klein, E., I. Ernberg, M. G. Masucci, R. Svizeti, Y. T. Wu, G. Masucci, and E. Svedmyr. 1981. T-cell response to B-cells and EpsteinBarr virus antigens in infectious mononucleosis. Cancer Res. 41:42104215.

17. Patel, P. C., G. Dorval, and J. Menezes. 1982. Cytotoxic effector cells from infectious mononucleosis patients in the acute phase do not specifically kill Epstein-Barr virus genome-carrying lymphoid cell lines. Infect. Immun. 38:251-259.

18. Purtilo, D. T., D. DeFloria, L. M. Hutt, J. Bhawan, J. P. S. Yang, R. Otto, and W. Edwards. 1977. Variable phenotypic expression of an X-linked recessive lymphoproliferative syndrome. N. Engl. J. Med. 297: 1077-1081.

19. Sullivan, J. L., K. S. Byron, F. E. Brewster, S. M. Baker, and H. D. Ochs. 1983. X-linked lymphoproliferative syndrome. Natural history of the immunodeficiency. J. Clin. Invest. 71:1765-1768.

20. Gerber, P., J. Whang-Peng, and J. H. Monroe. 1969. Transformation and chromosome changes induced by Epstein-Barr virus in normal human leukocyte cultures. Proc. Natl. Acad. Sci. USA. 63:740-747.

21. Rickinson, A. B., D. J. Moss, and J. H. Pope. 1979. Long-term 
T-cell immunity to Epstein-Barr virus in man. II, Components necessary for regression in virus infected leukocyte cultures. Int. J. Cancer. 23: 610-617.

22. Moss, D. J., A. B. Rickinson, and J. H. Pope. 1979. Long-term T-cell-mediated immunity to Epstein-Barr virus in man. III. Activation of cytotoxic T cells in virus-infected leukocyte cultures. Int. J. Cancer. 23:618-625.

23. Masucci, M. G., M. T. Bejarano, G. Masucci, and E. Klein. 1983. Large granular lymphocytes inhibit in vitro growth of autologous EpsteinBarr virus infected B cells. Cell. Immunol: 76:311-321.

24. Tosato, G., I. T. Magrath, and R. M. Blaese. 1982. T-cell-mediated immunoregulation of Epstein-Barr virus-induced B lymphocyte activation in EBV-seropositive and EBV-seronegative individuals. $J$. Immunol. 128:575-579.

25. Ziegler, J. L., W. L. Drew, R. C. Miner, L. Mintz, E. Rosenbaum, J. Gershow, E. T. Lennette, J. Greenspan, E. Shillitoe, J. Beckstead, C. Casavant, and K. Yamamoto. 1982. Outbreak of Burkitt's-like lymphoma in homosexual men. Lancet. ii:631-633.

26. Crawford, D. H., J. A. Thomas, G. Janossi, P. Sweny, O. N. Fernando, J. F. Moorehead, and J. H. Thompson. 1980. Epstein-Barr virus nuclear antigen positive lymphoma after cyclosporin A treatment in patient with renal allograft. Lancet. i:1355-1356.

27. Martin, P. J., H. M. Shulman, W. H. Schulbach, J. A. Hansen, A. Feter, G. Miller, and E. D. Thomas. 1984. Fatal Epstein-Barr-virusassociated proliferation of donor B cells after treatment of acute graftversus-host disease with a murine anti-T-cell antibody. Ann. Intern. Med. 101:310-315.

28. Rickinson, A. B., and D. J. Moss. 1983. Epstein-Barr virus induced transformation: immunological aspects. Adv. Viral Oncol. 3:213-238.

29. Tosato, G., and R. M. Blaese. 1985. Epstein-Barr virus infection and immunoregulation in man. Adv. Immunol. 37:99-149.

30. Benjamin, D., J. A. Berzofsky, I. J. East, F. R. N. Gurd, C. Hannum, S. J. Leach, E. Margoliash, J. G. Michael, A. Miller, E. M. Prager, M. Reichlin, E. E. Sercarz, S. J. Smith-Jill, P. E. Todd, and A. C. Wilson. 1984. The antigenic structure of proteins: a reappraisal. Annu. Rev. Immunol. 2:67-10i.

31. Henle, W., G. Henle, and C. A. Horowitz. 1974. Epstein-Barr virus diagnostic test in infectious mononucleosis. Hum. Pathol. 5:551565 .

32. Yarchoan, R., G. Tosato, R. M. Blaese, R. M. Simon, and D. L. Nelson. 1983. Limiting dilution analysis of Epstein-Barr virus-induced immunoglobulin production by human B cells. J. Exp. Med. 157:1-14.

33. Lawrence, E. C., R. M. Blaese, R. R. Martin, and P. M. Stevens. 1978. Immunoglobulin secreting cells in human bronchial lavage fluids. J. Clin. Invest. 62:832-835.

34. Tosato, G., R. Yarchoan, and R. M. Blaese. 1985. Relationship between immunoglobulin production and immortalization by EpsteinBarr virus. J. Immunol. 135:959-964.

35. Armstrong, J. A. 1971. Semi-micro, dye-binding assay for rabbit interferon. Appl. Microbiol. 21:723-725.

36. Klein, G., and E. Klein. 1984. The changing faces of EBV research. Proc. Med. Virol. 30:87-106.

37. Tosato, G., and R. M. Blaese. 1985. Defective allosuppression in patients with Ataxia-Telangiectasia. In Genetics, Neuropathology and Immunology of a Degenerative Disease of Childhood. R. A. Gatti and M. Swift, editors. Alan R. Liss, Inc., New York. 331-338.

38. Moss, D. J., A. B. Rickinson, and J. H. Pope. 1978. Long-term T-cell-mediated immunity to Epstein-Barr virus in man. I. Complete regression of virus-induced transformation in cultures of seropositive donor leukocytes. Int. J. Cancer. 22:662-668.

39. Henle, G., and W. Henle. 1979. Seroepidemiology of the virus. In The Epstein-Barr Virus. M. A. Epstein and B. G. Achong, editors. Springer-Verlag, Berlin. 61-79.

40. Diehl, V., G. Henle, W. Henle, and G. Kohn. 1968. Demonstration of a herpes group virus in cultures of peripheral leukocytes from patients with infectious mononucleosis. $J$. Virol. 2:663-669.

41. Thorley-Lawson, D. A., L. Chess, and J. L. Strominger. 1977. Suppression of in vitro Epstein-Barr virus infection. A new role for the adult human T lymphocyte. J. Exp. Med. 146:495-508.

42. Rickinson, A. B., L, E. Wallace, and M. A. Epstein. 1980. HLArestricted T-cell recognition of Epstein-Barr virus-infected B cells. Nature (Lond.). 283:865-867.

43. Lotz, M., G. D. Tsoukas, S. Fong, D. A. Carson, and J. H. Vaughan. 1985. Regulation of Epstein-Barr virus infection by recombinant interferons. Selected sensitivity to interferon- $\gamma$. Eur. J. Immunol. 15:520-525.

44. Twomey, J. J. 1974. Abnormalities in the mixed leukocyte reaction during infectious mononucleosis. J. Immunol. 112:2278-2281.

45. Mangi, R. J., J. C. Niederman, J. E. Kelleher, J. M. Dwyer, A. S. Evans, and F. S. Kantor. 1974. Depression of cell-mediated immunity during acute infectious mononucleosis. $N$. Engl. J. Med. 291: $1149-1153$.

46. van Oers, M. H. J., J. Pinkster, and W. P. Zeiglemaker. 1978. Quantification of antigen-reactive cells among human T lymphocytes. Eur. J. Immunol. 8:477-484.

47. De Waele, M., C. Thielemans, and B. K. G. Van Camp. 1981. Characterization of immunoregulatory $\mathrm{T}$ cells in EBV-induced infectious mononucleosis by monoclonal antibodies. N. Engl. J. Med. 304:460462.

48. Grimm, E. A., H. Z. Zhang, A. Mazunder, and S. A. Rosenberg. 1982. Lymphokine-activated killer cell phenomenon. Lysis of natural killer-resistant fresh solid tumor cells by interleukin 2-activated autologous human peripheral blood lymphocytes. J. Exp. Med. 155:1823-1841. 